\title{
GLAZBENI PISAC VJENCESLAV NOVAK
}

Sanja Majer-Bobetko

Hrvatska akademija znanosti i umjetnosti

Zavod za povijest hrvatske književnosti, kazališta i glazbe

Odsjek za povijest hrvatske glazbe

Opatička 18

HR 10000 Zagreb

sanjamajerbobetko@gmail.com
UDK: 78:929Novak, V. Izvorni znanstveni članak

Ur.: 2019-12-12

Vjenceslav Novak hrvatskoj je kulturnoj javnost uglavnom znan kao književnik. Manje je poznato da je bio jedan od rijetkih hrvatskih glazbenika sa završenim formalnim visokim glazbenim obrazovanjem te je egzistenciju sebi i obitelji osiguravao kao profesor različitih glazbenih predmeta.

Usto je od 1888. godine petnaestak godina objavljivao brojne članke u periodici i monografska izdanja. Ti radovi razotkrivaju široku lepezu Novakovih profesionalnih zanimanja: od glazbene kritike preko teorije, pedagogije, metodike, organologije i estetike glazbe, do glazbene historiografije, što ga, uz utemeljitelja hrvatske muzikologije uopće, Franju Ksavera Kuhača, čini vodećim glazbenim piscem s prijeloma 19. i 20. stoljeća.

Ključne riječi: Vjenceslav Novak, glazbeni pisac, glazbena kritika, glazbena pedagogija, glazbena historiografija, povijest hrvatske glazbe

\section{Uvod}

U kolektivnoj memoriji Vjenceslav Novak većinom je zabilježen kao književni predstavnik realizma. Manje je znano da je on bio jedan od onodobnih rijetkih hrvatskih glazbenika sa završenim formalnim visokim glazbenim obrazovanjem.

Novak je, naime, nakon završene preparandije u Zagrebu i učiteljevanja u Senju, studirao na Praškom konzervatoriju od 1884. do 1887., gdje je 1886. stekao zvanje orguljaša, a 1887. nastavnika pjevanja i teorije glazbe. Također je manje poznato da je do smrti svoj "svakodnevni kruh", kojim je osiguravao egzistenciju sebi i svojoj brojnoj obitelji, zarađivao kao profesor glazbe u Muškoj učiteljskoj školi u Zagrebu. Usto je od 1890. do 1894. predavao i teoriju, glazbenu estetiku i povijest glazbe na školi Narodnoga zemaljskoga glasbenoga 
zavoda (danas: Hrvatski glazbeni zavod), a počevši od 1888. godine petnaestak je godina bio intenzivno prisutan u hrvatskom kulturološkom i glazbenom prostoru, poglavito svojim člancima u periodici i monografskim izdanjima.

$\mathrm{Ti}$ radovi razotkrivaju široku lepezu Novakovih profesionalnih zanimanja: od glazbene kritike preko glazbene teorije, pedagogije, metodike, organologije i estetike glazbe, do glazbene historiografije, što ga, uz utemeljitelja hrvatske muzikologije uopće, Franju Ksavera Kuhača, čini vodećim glazbenim piscem s prijeloma 19. i 20. stoljeća. Napokon, kako je poznato, glazbene teme našle su mjesta i u njegovom književnom opusu u djelima Dva svijeta i Informator. Nije mu bilo strano ni skladanje, ali su njegove skladbe većim dijelom izgubljene. Koliko je poznato, pisao je uglavnom za zborove, primjerice za Hrvatsko pjevačko društvo "Kolo", zatim za orgulje i popijevke. Usto je harmonizirao 52 napjeva iz zbornika crkvenih pjesama na hrvatskom i latinskom jeziku Cithara octochorda (1701., 1723., 1757.) te ih objavio u Zagrebu 1891. godine pod naslovom Starohrvatske crkvene popijevke. ${ }^{1}$

Svoje glazbeno-spisateljsko djelovanje počeo je, kako je navedeno, 1888. godine i to opsežnom raspravom o pučkom učitelju kao učitelju pjevanja i orguljašu, ${ }^{2}$ dakle problematikom vezanom uz njegovo primarno pedagoško djelovanje, s jedne strane, te kao glazbeni kritičar Narodnih novina i Vienca, s druge strane.

\section{Glazbeno-pedagoški radovi}

Pedagoškom području pripadaju i prvi udžbenici harmonije na hrvatskom jeziku, kojima je autor također Vjenceslav Novak. Riječ je o Pripravi k nauci o glazbenoj harmoniji i Nauci o glasbenoj harmoniji. ${ }^{3}$ Namijenio ih je za uporabu u učiteljskim školama, a glavni cilj bio mu je, prema vlastitim riječima, "podati pravila o sastavbi suzvuka i njihovu spajanju učenicima, koji se nijesu lih glazbenoj obuci posvetili, u najlakše shvatljivom i za praktičnu uporabu upriličenom obliku,"4 a u drugom izdanju Nauke o glazbenoj harmoniji dodao je i poglavlje o modulacijama, "vještini," kako on ističe, "bez koje se ne može ni lošega orguljaša pomisliti." 5

${ }^{1}$ O Novakovoj zbirci usp. N. s. M. TABAK, 2001, 412-420.

${ }^{2}$ Usp. V. NOVAK, 1887-88, 3-24; 1888, 225-227, 243-245, 259-260, 275-277, 293-294, 310-311, 325-326.

${ }^{3}$ Usp. V. NOVAK, 1889, 1890, 1898.Ovdje valja istaknuti da je veći dio rukopisa na njemačkom jeziku Theorie der Tonsetzkunst, odnosno u prijevodu Teorije sloga tonske umjetnosti, Vatroslava Lisinskog posvećen harmoniji. O tome usp. K. KOS, 1969, 279-286.

${ }^{4}$ V. NOVAK, 1898, npg.

${ }^{5}$ Ibid. 
U ovu skupinu njegovih radova svakako valja ubrojiti i Uputu $u$ orguljanje, namijenjenu poduci u sviranju orgulja ${ }^{6}$ te brojne druge radove, $\mathrm{u}$ kojima progovara o različitim temama, od najopćenitijeg pregleda povijesti glazbenog školstva ${ }^{7}$ i pitanja odnosa glazbe i odgoja, gdje se dotiče i glazbenosociološke problematike nezadovoljavajućeg društvenog položaja glazbe i glazbenika, ${ }^{8}$ do obuke pjevanja, ${ }^{9}$ što uključuje problematiku dječjeg zdravlja, ${ }^{10}$ mutiranja ${ }^{11}$ teorije glazbe ${ }^{12}$ i metodike. ${ }^{13}$ Ovdje, međutim, valja upozoriti na vrlo široko shvaćanje discipline teorije glazbe. Njome, naime, Novak obuhvaća akustiku, teoriju glazbe u užem smislu, harmoniju, kontrapunkt, glazbene oblike, estetiku i povijest glazbe, ${ }^{14}$ a svakoj je od njih u svojim napisima posvećivao posebnu pozornost. Naposljetku, svojevrsnu sintezu svojih glazbeno-pedagoških promišljanja izložio je u Pedagogijskoj enciklopediji gdje odgovara i na temeljno pitanje što je cilj glazbenog obrazovanja uopće: "Cilj se glazbenoj obuci stoji u tom, da se učenik dovede do toga, da razumije glazbenu umjetnosti, da mu se oplemeni ukus i da bude u shvaćanju glazbene umjetnosti, dakle i u svom sudu o njoj samostalan."15

\section{Glazbena kritika}

Nastavivši tradiciju hrvatskih književnika, od Demetra i Vraza do Šenoe, koji su se bavili hrvatskom glazbenom kritikom, a zapravo je i utemeljili, ${ }^{16}$ te

${ }^{6}$ Usp. V. NOVAK, 1893.

${ }^{7}$ Usp. V. NOVAK, 1895-1906, 392-393; 1901a, 386-392.

${ }^{8}$ Usp. V. NOVAK, 1892, 2-3, 9-11, 17-18.

${ }^{9}$ Usp. V. NOVAK, 1889-90, 3-14; 1890a, 233-236, 248-251; 1901, 310-320; 1900a, 372-378.

${ }^{10}$ Usp. V. NOVAK, 1892a, 4-5; Idem, 1892c, 36-37.

${ }^{11}$ Usp. V. NOVAK, O mutaciji grla, 1892b, 33-35.

${ }^{12}$ Usp. V. NOVAK, 1889b, 19-23; Idem, 1891, 3-7; 1892d, 47, 50-51; Idem, 1893c, 13-14; Idem, 1898-1899a, 279-280, 302-303, 327-329; Idem, 1899-1900, 9-11, 35-36+38-39, 86-88; Idem, 1899-1900b, 155-156, 177-179, 207-209, 238-239; Idem, 1900a, 372-378.

${ }^{13}$ Usp. V. NOVAK, 1892f, 44-58; Idem: 1893c, 13-14.

${ }^{14}$ Usp. V. NOVAK, 1892d, 51.

${ }^{15}$ V. NOVAK, 1901a, 387.

${ }^{16}$ Povijest hrvatske glazbene kritike započinje 1826. godine tekstom nepoznatog autora (u potpisu stoji '-au-') na njemačkom jeziku u književno-zabavnom časopisu Luna. Riječ je o osvrtu na melodramu Viola Josepha Auffenberga sa scenskom glazbom Karla Georga Wisnera von Morgensterna. Desetljeće kasnije, pokretanjem Novina Horvatskih i Danice Horvatske 1835., otvara se prostor glazbenoj kritici i na hrvatskom jeziku, početak koje je obilježen prilozima hrvatskih književnika, poglavito Dimitrije Demetra od 1839. Prvom hrvatskom glazbenom kritikom u punom smislu riječi drži se kritika praizvedbe Lisinskijeve opere Ljubav i zloba, koja se atribuira Stanku Vrazu (1846.). 
pridruživši se suvremeniku mu Antunu Gustavu Matošu, Novak i sam svoje javno djelovanje glazbenog pisca počinje, uz navedeni rad pedagoške tematike, kao glazbeni kritičar. Već je prva njegova glazbena kritika operete Afrodita izazvala polemički odgovor njezina libretista Nikole Milana Simeonovića. ${ }^{17}$ Oštro Novakovo kritičko pero obrušilo se naime upravo na libreto dok "o glasbi ove operete možemo - hvala Bogu", kako piše Novak, "drugačije govoriti. Zajc je slabi ovaj libreto zaodjeo mjestimice upravo krasnom glasbom." Ipak ističe da se ni glazbi "ne može doduše podpuna originalnost priznati, ali je provedena majstorski."18 Ne odstupivši od svojih prijašnjih kritičkih opaski, polemiku je zaključio Novak. Njegove ne odveć brojne glazbene kritike uglavnom razotkrivaju kritičara koji teži, a često i uspijeva svoje stavove argumentirano stručno obrazložiti, koliko je to bilo moguće u okvirima standardâ propisanih dnevnim tiskom.

Području kritike pripadaju i Novakove recenzije notnih izdanja, koje također razotkrivaju njegov stručni potencijal. O tome zorno svjedoče recenzije zbirki slavenskih narodnih pjesama češkog etnologa, folklorista, muzikologa i slikara Ludvíka Kube (1863. - 1956. ${ }^{19}$ i narodnih pjesama različitih naroda Karla Augusta Hermanna. ${ }^{20}$ Autora potonje podvrgava žestokoj kritici poglavito zbog neuvrštavanja slovenskih i hrvatskih popijevaka. Hermann je u svoju zbirku uvrstio samo dvije srpske popijevke, a Novak jednu od njih identificira prema Kuhačevoj zbirci Južno-slovjenskih narodnih popievaka kao hrvatsku pjesmu iz Slavonije. Možda je ponajbolji primjer Novakova recenzentskog rada recenzija zbirke popijevaka Vatroslava Lisinskoga, što ju je pod naslovom Neuvelo cvieće objavio Franjo Ksaver Kuhač. Novak ovdje znalački i autoritativno analizira odnos teksta i glazbe, vokalne dionice i glasovirske pratnje, melodijsku, harmonijsku, ritamsku, tonalitetnu strukturu, gdjekad i uz notni primjer (Sl. 1). ${ }^{21}$

Kraće su, ali dovoljno informativne u pogledu skladateljskog glazbenog izričaja recenzije dviju skladbi, obje također objavljene u Viencu. Riječ je o sljedećim skladbama: muškom zboru Divici Mariji (na tekst Marka Marulića) senjskog kapelnika, orguljaša i crkvenog zborovođe Karela Kukle ${ }^{22}$ te Zbirci popievaka Karla Piente. ${ }^{23}$ Kuklinim skladbama, konkretno njegovim trima

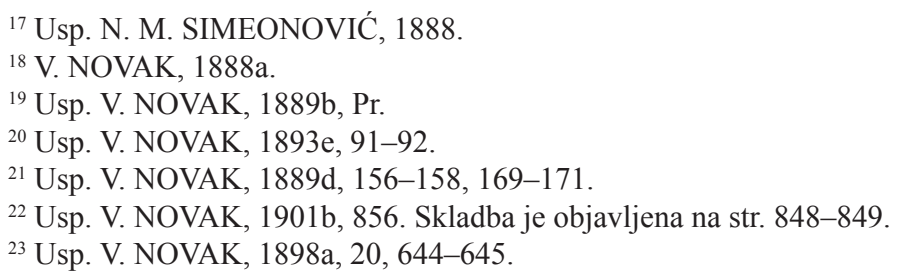




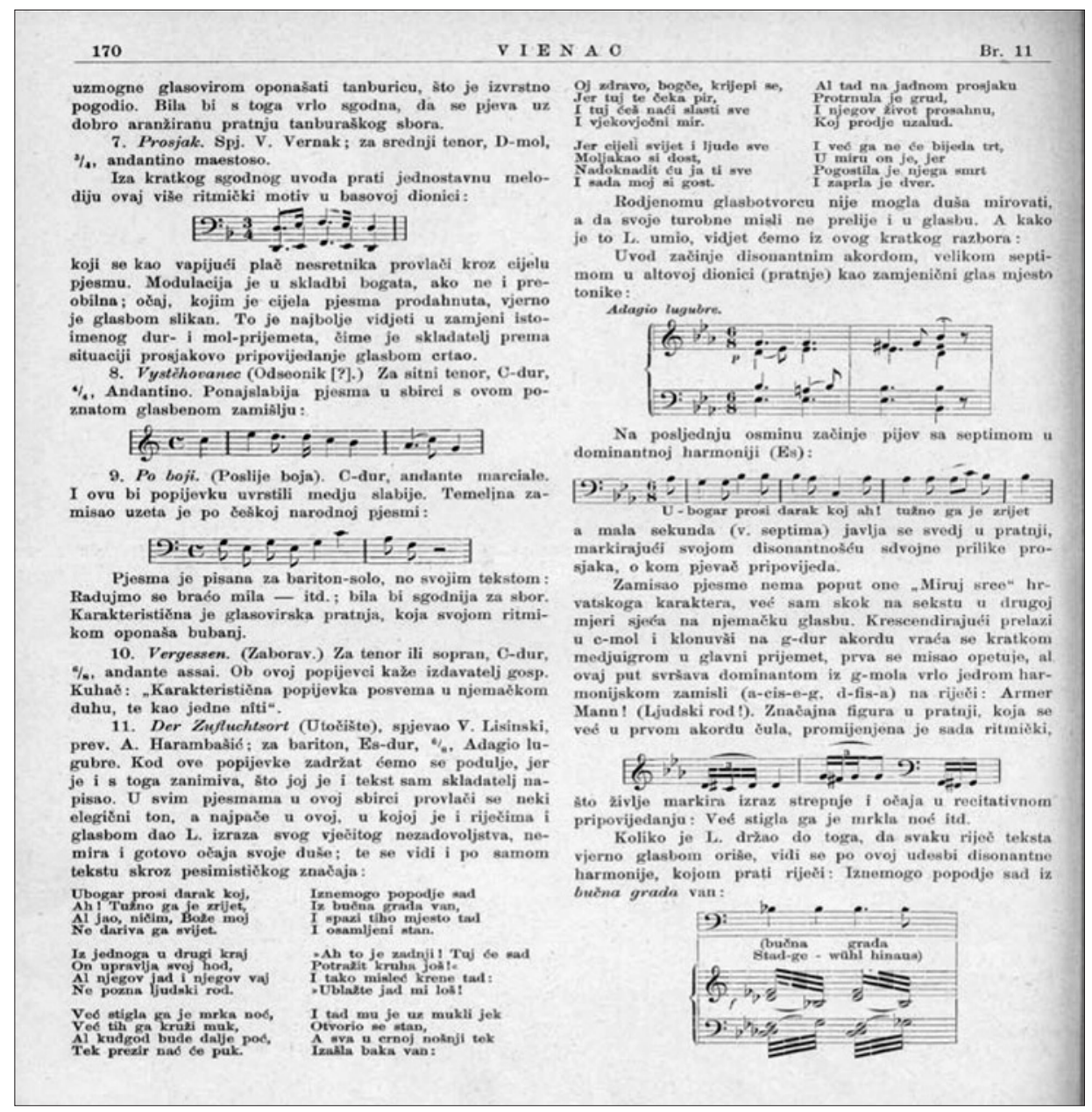

S1. 1. Vjenceslav Novak, ulomak iz recenzije zbirke popijevaka Neuvelo cvieće Vatroslava Lisinskoga u izdanju Franje Kuhača,

(Vienac, 21/10, 21/11, Zagreb, 1889, 156-158, 169-171)

misama na starohrvatske tekstove, posvećena je i zasad posljednja registrirana recenzija Vjenceslava Novaka. ${ }^{24} \mathrm{U}$ ovoj recenziji, koja je također zasnovana na glazbenoj analizi, Novak međutim u opsežnom uvodnom dijelu podvrgava oštroj kritici onodobno stanje u hrvatskoj crkvenoj glazbi, ocjenjujući ga uglavnom diletantskim, a potom kraćim biografskim osvrtom predstavlja i češkog

${ }^{24}$ Usp. V. NOVAK, 1903, 196-197, 261-263. 
skladatelja Karela Kuklu te također diletantsko glazbeno okružje kakvo je Kukla zatekao u gradu Senju. Unatoč tome skladao je te tri mise, o kojima Novak ingeniozno zaključuje da "odišu u svim dijelovima jedinstvenom ozbiljnošću i dostojanstvom i dojimlju se kao moderna crkvena skulptura ili slikarstvo s aluzijom na antiknu crkvenu tradiciju."25

\section{Glazbena historiografija}

Već 1889. godine Novak širi svoju paletu tema na glazbenu historiografiju, koja će, uz pitanja iz područja glazbene estetike, ostati u žarištu njegova zanimanja.

Svojim prvim glazbenohistoriografskim radom Crtice o razvoju crkvene glasbe našao se opet u vrtlogu polemike, ovaj put s Mijom Majerom. ${ }^{26}$ Tim svojim ovećim radom Novak je izložio povijesni pregled crkvene glazbe od srednjovjekovnog gregorijanskog korala do 19. stoljeća te je progovorio i o crkvenoj glazbi u Hrvata, o praksi u hrvatskim crkvama, o crkvenim pjesmaricama, o savjetima učiteljima i svećenicima za pravilnu uporabu i njegovanje crkvene glazbe. ${ }^{27}$

Među ostale njegove glazbenohistoriografske radove valja uvrstiti sljedeće: biografske članke Gjuro Eisenhut ${ }^{28}$ Richard Wagner, ${ }^{29}$ Ambroise Thomas $^{30} \mathrm{i}$ Ivan pl. Zajc, ${ }^{31}$ za kojega je još za Zajčeva života pronicljivo prorekao "da će ga povijest hrvatske glazbe o našem vremenu postaviti kao stožer, koji u razvitku njezinom bilježi jednu periodu", ${ }^{32}$ zatim članak "Počeci višeglasja do Palestrine", ${ }^{33}$ već citiran enciklopedijski članak "Glazbene škole", u kojemu Novak daje kratak pregled povijesti glazbenog školstva u Europi i u Hrvatskoj, te poglavlje "Historički razvitak obuke u pjevanju" iz također već navedenog djela Pjevačka obuka u pučkoj školi. Potonje je zapravo prvi hrvatski pregled

${ }^{25}$ Ibid., 262. K. Kukla je djelovao u Senju od 1891. do 1905., a potom kao nastavnik pjevanja i orguljaš u gimnaziji te voditelj pjevačkih društava "Jadranska vila" i "Primorski Hrvat" na Sušaku (od 1906. do 1912.), gdje je 1913. i umro.

${ }^{26}$ Usp. M. MAJER, 1889, 207; V. NOVAK, 1889c.

${ }^{27}$ Usp. V. NOVAK, 1888-1889, 3-20; 1889a, 260-263, 275-278, 290-294. O tome usp. G. DOLINER, 2009, 115-118.

${ }^{28}$ Usp. V. NOVAK, 1893d, 57-59.

${ }^{29}$ Usp. V. NOVAK, 1899-1900c, 437-439, 459-462.

${ }^{30}$ Usp. V. NOVAK, 1898-99, 99+108-110.

${ }^{31}$ Usp. V. NOVAK, 1893a, 1-3; 1899-1900a, 31, 104-105.

${ }^{32}$ Usp. V. NOVAK, 1899-1900a, 104.

${ }^{33}$ Usp. V. NOVAK, 1900, 42-45, 62-67. 
povijesti metodike pjevanja, poglavito u pučkoj školi, s pojedinim aspektima povijesti vokalne glazbe uopće, ne samo s metodičkog stajališta.

Međutim, povijest vokalne glazbe još je opsežnije predstavljena u članku "Počeci višeglasja do Palestrine". Riječ je očito o Novakovu predavanju održanom na dobrotvornom koncertu (za siromašne učenike) učiteljskih pripravnika u Zagrebu 2. veljače 1900. Tom je zgodom slušateljstvu predočio niz tada već utvrđenih povijesnih činjenica, predstavivši se pritom kao povjesničar glazbe kojemu je dobro znana europska relevantna literatura, $\mathrm{s}$ jedne strane, ali i kao takav povjesničar kojemu nije strano promišljanje povijesnih tema i s motrišta glazbene estetike, pa i psihologije glazbe, s druge strane, što mu s pravom pribavlja epitet originalnog povjesničara. Naime, nakon što su učiteljski pripravnici i učenici vježbaonice otpjevali jedan primjer za ilustraciju organuma, ${ }^{34}$ Novak je, anticipirajući vizionarski neke od postavki suvremene estetike i psihologije glazbe, koja upozorava na povijesnost glazbene percepcije, ${ }^{35}$ zaključio:"Kako ste izvoljeli čuti, nije taj dvopjev nikakva naslada za naše moderno uho; no rečeni opat Hucbald bio je od njega toliko zanesen, te je, kako sam pripovijeda, proplakao od milja slušajući ga. Mi ljudi XIX. stoljeća po svom estetskom glazbenom ukusu ne podnosimo tog niza samih praznih intervala; naša moderna teorija zabranjuje po pradavnim svojim pravilima u višeglasju, takve usporedne pomake kvartâ i kvintâ. A kako se dovinuše ljudi takvoga dvoglasja pred 1000 godina? Je li to zavedeno na osnovu starogrčke glazbene teorije o simfoniji i diafoniji, t. j. konsonantnosti i disonantnosti, kako bi mi danas rekli? Jer kvinte su iza unisona i oktava najsavršenije konsonance: Je li dakle koji teoretičar izumio takvo pravilo, držeći da se nizom samih konsonanca mora razblažiti ljudsko uho?Ili se takvi organum pojavio prije u praksi, pa istom onda - kao što to gotovo redovno kod umjetnosti biva - ušao u teoriju? Na to ne možemo stalno odgovoriti. - Ima glazbenih historičara i estetika među njima čuvena imena, kao što su n. pr. Kiesewetter i Oskar Paul, koji tvrde, da je takvo dvoglasje moralo biti ljudskomu uhu nesnošljivo i pred 1000 god. kao što je i danas. Oni stoga uzimaju, da je organum bio ili samo teoretski pokus, ili da su viša grla izvodila melodiju jednoglasno, a niža opet jednoglasno za njima istu melodiju za kvintu niže. No čini se, da ta tvrdnja ne stoji. Estetsko poimanje glasova mijenjalo se, kao što se mijenja i danas (kurziv S.M.B.)."36

\footnotetext{
${ }^{34}$ Notnim pismom primjer je zabilježen u ibid., 43.

${ }^{35}$ Usp. Z. LISSA, 1977, 71-86.

${ }^{36}$ V. NOVAK, 1900, 43.
} 
Zagrebačkom Straussu, kako se znalo zvati Gjuru Eisenhutha, posvetio je Novak biografski članak. Unatoč činjenici da je to bio prvi opsežniji članak o Eisenhuthu objavljen nakon njegove smrti, u kojemu je štoviše prvi put objavljen popis svih Eisenhuthovih djela, što ga je Eisenhuth učinio sam, hrvatska ga je glazbena historiografija potpuno zanemarila i zaboravila, kao uostalom i samoga Eisenhutha, sve do dvadesetih godina 20. stoljeća. Tada, inače krajnje pedantan Antun Goglia, objavljuje u svojoj studiji o Eisenhuthu i popis njegovih djela, ali uopće ne spominjući Novakov članak. ${ }^{37}$ Za razliku od Goglie, koji je u sferi glazbe ipak samo amater i koji se s pravom ne usuđuje vrednovati glazbena djela te se mudro zadržava na razini dokumentarističkih studija, Vjenceslav Novak, koji je pak autor s glazbenim obrazovanjem najviše razine, svoj članak otvara prosudbom skladateljstva Gjure Eisenhutha: "Od hrvatskih glazbenika spominje se uza Zajca najviše Eisenhutovo ime, jer nema pjev. društva u Hrvatskoj, koje ne bi u svom repertoiru imalo koju tu kompoziciju pok. Gjuke. Sudimo li toga hrv. glazbenika po njegovim radnjama, očituje se u njegovim skladbama po obliku, obradbi, kretu pojedinih dionica i često vrlo nedošljednoj provedbi inače krasnih muzikalnih zamišljaja, da nije prošao strogu i oporu školu glazbene skladbouke; pa ipak su navlastito njegovi muški zborovi toliko zavoljeni u hrvatskom narodu, da ćete se danas rijetko namjeriti na program kojega hrv. pjev. društva u kom ne bi našli Eisenhutovo ime. Kako to? Tako, jer je pokojni Gjuka bio glazbenik po srcu, jer je glazbenom umjetnošću bila prožeta njegova krv, jerbo je mislio, osjećao i umio govoriti tonovima. I kad na to pomislimo, da je taj rodjeni glazbeni poeta postao ono, što je bio, samo kao samouk; da nije sistematično i bistro zagledao u tajne glazbene umjetnosti: Moramo tri puta požaliti, što je mogao svomu narodu prikazati samo dijelak svoga krasnoga talenta i božanskoga nadahnuća."

Drugi glazbenohistoriografski biografski članak posvećen je Richardu Wagneru i njegovoj opernoj reformi, što je bila jedna od ključnih tema Novakovih suvremenika, kako inozemnih tako i hrvatskih. Zato ne čudi da su sva trojica vodećih autora na području onodobne hrvatske glazbene historiografije Vjekoslav Klaić, Franjo Ksaver Kuhač i Vjenceslav Novak - progovorili o toj reformi.

Kuhaču je, poput brojnih drugih radova, i članak o Wagneru poslužio za promidžbu njegovih temeljnih stavova o glazbi kao promicateljici nacionalnog identiteta, ${ }^{38}$ što uopće ne krije već jasno ističe razloge svoga pisanja o Wagneru:

${ }^{37}$ Usp. A. GOGLIA, 1926, 37-48.

${ }^{38} \mathrm{O}$ tome usp. S. MAJER-BOBETKO, 1979, 17-29; Idem, 1984, 441-459. 


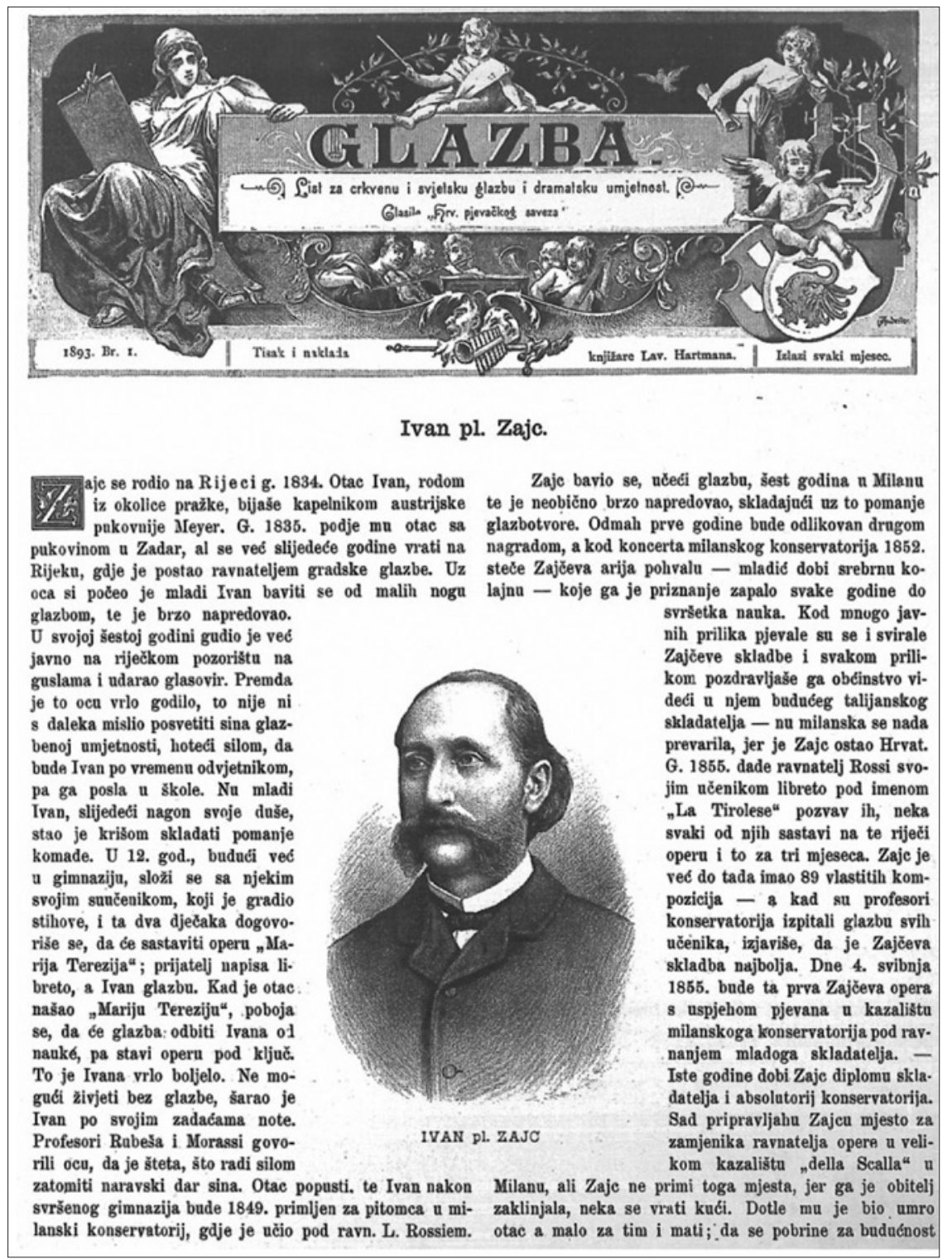

S1. 2. Vjenceslav Novak, Ivan pl. Zajc, Glazba, 1/1, Zagreb, 1893, 1-3. Atribucija: Sanja Majer-Bobetko prema usporedbi s člankom Ivan pl. Zajc, Pobratim, 10/2, 10/5, Zagreb, 1899-1900, 31, 104-105.

(izvor: https://digitalnezbirke.kgz.hr/?object=view\&hash=pL4K3f59KP)

$$
\text { (2019-12-12) }
$$


"Scienim da je to već s toga potrebno, da dadem našim hrvatskim komponistima pa i našem općinstvu ako baš ne direktivu, a to bar neko uporište, da znadu kako bi trebalo, da se Hrvati drže napram Wagnerovom smjeru." ${ }^{139}$ A trebali bi se držati ovako: "Opera se ne smije uništiti Wagnerovim melodramama za volju; u glazbi ne smijemo iskoreniti melodiju, glazbene forme i logičnu simetriju, a nipošto ne smijemo odustati od narodnoga principa u glazbi." ${ }^{40}$ Međutim, postoji i iznimka, koja se odnosi na hrvatske opere skladane na slavenske mitološke teme. Takvim bi opernim djelima odgovarale postavke Wagnerove reformirane opere jer, kako piše Kuhač, "kada bi pjevao Svarog, Perun ili drugo koje mitološko božanstvo melodiju u današnjem smislu hrvatske glazbe, reklo bi općinstvo, da to ne odgovara istini, te bi izgubilo i svu iluziju. Nasuprot ako pjevaju takve mitološke osobe recitativno, monotono, na dugo i široko, kako pjevaju i naši pučki guslari, mogao bi slušatelj predmnievati, da su se ti bogovi po prilici tako izrazili." 41

Za razliku od Kuhača Klaić i Novak su se klonili ideologiziranja i opernu su reformu svojem čitateljstvu izložili s povijesnih i estetičkih motrišta. Premda obojica donekle suzdržano, ipak naglašavaju da je riječ o golemom i opravdanom zahvatu u operno tkivo. Klaić pritom jasno ističe da nije ljubitelj i "štovalac" Wagnerove glazbe, ali njegovu reformu u potpunosti odobrava jer "opera - ta pjevana drama - mora i glasbom svojom izticati, da je drama, a ne pjesma ili niz pjesama i pjesmica, sbijenih u cjelinu. On se je zato klonio zaokruženih oblika (arija, kavatina, dvopjeva), koji se u dosadanjih operah nižu jedan za drugim, te je nastojao, da operu pretvori u neprekinutu glasbenu deklamaciju, kojoj bi jaka, bujna i raznolika pratnja podavala što veću slikovitost. Glasba dakle neka uviek zvukovi i skladom prikaže, što nam tekst riečima govori. Wagner je tu svrhu svoju podpuno polučio: recitativi i sjajna, bujna instrumentacija njegovih djela svjedoče o tom." ${ }^{42}$

Ističući da ne želi donositi prosudbu glasovitog sukoba wagnerijanaca i antiwagnerijanaca i zauzimati jednu od sukobljenih strana, Novak se priklanja povjesničarskoj razboritosti: "Svakako morat će priznati i Wagnerovi protivnici, da je starija operna glazba poradi apsolutnih glazbenih forma vrlo često sasvim napuštala s vida dramu idući za vanjskim efektom, pa bilo to i sredstvima, kojima se s gledišta čiste glazbene umjetnosti ne može prigovoriti." ${ }^{13}$ Kako bi

\footnotetext{
${ }^{39}$ F. Ks. KUHAČ, 1897, 91.

${ }^{40}$ Ibid., 111.

${ }^{41}$ Ibid.

${ }^{42}$ V. KLAIĆ, 1883, 133-134.

${ }^{43}$ V. NOVAK, 1899-1900c, 438.
} 
se Wagnerovi zahvati u strukturu opere što bolje razumjeli, Novak čitatelja prvo upoznaje s kratkim pregledom povijesti opere, sjajno pritom akcentuirajući ključne momente toga razvoja. "Držim, da će sada [nakon povijesnog pregleda, op. S.M.B] biti jasna težnja Wagnerova za preporodom glazbe" ${ }^{44}$ ističe sam Novak, koji tek nakon tog povijesnog uvoda pristupa znalački izvedenom analitičkom prikazu same reforme.

Središnje mjesto u glazbenohistoriografskom opusu Vjenceslava Novaka pripada njegovoj monografiji [Povijest glazbe]. Riječ je o pionirskom pothvatu u povijesti hrvatske glazbene historiografije, odnosno o prvoj hrvatskoj glazbenohistoriografskoj sintezi, koja sedugo se držala izgubljenom. ${ }^{45}$ Tako je nekih stotinjak godina ostala nepoznatom, barem široj glazbenoj javnosti. Tek 1994., točno sto godina nakon narudžbe ravnateljstva HGZ-a kojom se od Vjenceslava Novaka naručuje da napiše povijest glazbe, ${ }^{46}$ objavljeno je njezino kritičko izdanje. ${ }^{47}$ Međutim, u rukopisnom se obliku koristilau nastavi na Muzičkoj akademiji u Zagrebu i nakon I. svjetskog rata ${ }^{48}$ Prema svim dostupnim podacima Novak je svoju [Povijest glazbe] pisao tijekom druge polovice zadnjeg desetljeća 19. stoljeća te ga završio i predao 1900. godine. U današnjem nepotpunom stanju u kojemu rukopisu nedostaju prva i posljednja stranica, dijelovi teksta od 54. do 73. stranice i 218. stranica, ta je [Povijest glazbe] 1945. prispjela u knjižnicu Muzičke akademije u Zagrebu. U inventarnoj knjizi, nažalost, nema nikakve napomene o načinu na koji je postala njezinim vlasništvom.

Ovim je rukopisom Novak nedvojbeno pokazao zavidan stupanj poznavanja relevantne literature. Kao praškom đaku poznata mu je i u samom njegovu tekstu apostrofirana opsežna Geschichte der Musik uglednog i utjecajnog povjesničara češkog podrijetla Augusta Wilhelma Ambrosa (1816. - 1876.). ${ }^{49}$ Međutim, Novak se našao pred specifičnim zadatkom pisanja udžbenika, što je zahtijevalo spajanje temeljnih informacija iz područja povijesti glazbe s praktičnim, odnosno propedeutičkim i metodičkim

${ }^{44}$ Ibid., 439.

${ }^{45}$ Usp. L. ŠABAN, 1982, 113.

${ }^{46}$ Usp. ibid.

${ }^{47}$ Usp. V. NOVAK, 1994, 1-200.

${ }^{48}$ Usp. D. FRANKOVIĆ, 2002, 19-34.

${ }^{49}$ Usp. V. NOVAK, 1994, 111. Ambros nije uspio sam dovršiti svoje djelo. Tako su 4. svezak uredili C. V. Becker i G. Nottebohm, a 5. svezak je uredio O. Kade (1882.). Langhansova Die Geschicthe der Musik des 17., 18. und 19. Jahrhunderts (1881. - 1887.) zamišljena je kao nastavak Ambrosove povijesti. 
zahtjevima u samoj pedagoškoj praksi. Da je bio potpuno svjestan takvih zahtjeva, svjedoče njegove vlastite riječi: "Školska knjiga zahtijeva u prvom redu logični razpored gradiva, jasnoću u izražaju misli, lahak stil, pa shvatljiv i pravilan jezik." ${ }^{50}$ A tome su bolje od Ambrosove odgovarale tri tada već afirmirane sažete, popularne povijesti glazbe: 1. Bernhard Kothe, Abriss der allgemeinen Musikgeschichte. Für Lehrerseminare und Dilettanten (Leuckart, Leipzig, 1874.); ${ }^{51}$ 2. Robert Paul Joh. Musiol, Katechismus der Musikgeschichte (J. J. Weber, Leipzig, 1877.).52 3. Emil Naumann, Illustrierte Musikgeschichte (2 sv., Spemann, Berlin - Stuttgart 1880. - 1885.). ${ }^{53}$ Premda je Naumannova Povijest svakako najiscrpnija i najopsežnija, Novak se najvećim dijelom oslanjao na Kotheovu Povijest, povremeno se služeći i podacima iz ostalih navedenih izvora, napose Naumannova djela. O tome svjedoči sam početak rukopisa. Kothe naime počinje svoju povijest razvojem glazbe antičke Grčke (barem u izdanjima dostupnima Novaku, što su priređivači kasnijih izdanja promijenili), dok se u Novaka, po uzoru na Naumanna, taj početak pomiče na stare civilizacije, aprema Musiolu vrši opću periodizaciju glazbene povijesti u tri velika odsjeka. Za Musiola ta su tri razdoblja: razdoblje antičke glazbe, kršćanske glazbe i nove glazbe. Za Novaka ta su tri razdoblja: "a) glazba starih naroda do kršćanske dobe; ta se perioda počinje kulturnim razvitkom starih naroda i traje do kršćanske dobe; b) kršćanska glazba, što traje od prilike do godine 1600., kad se je stao uvoditi naš diatonski i kromatički sistem i c) doba procvata dramatske i klasične glazbe, te najnovija nastojanja od 1600. pa do danas." ${ }^{54}$

Unatoč terminološkim razlikama ta periodizacija "zvuči" kao anticipacija tona koji pripada sljedećem akordu. Ne može se ne uočiti sličnost s jednom od prvih velikih periodizacija glazbenih stilova kroz povijest, onom Guida Adlera (1855. - 1941.). Dok je u Novaka povijest glazbe podijeljena na tri velika razdoblja, u

${ }^{50}$ V. NOVAK, 1889b, 23.

${ }^{51}$ Knjiga Bernharda Kothea (1821. - 1897.) je stekla zaista golemu popularnost i doživjela velik broj izdanja. Tako je 11. dopunjeno izdanje uredio R. F. Procházka 1926. godine, a 12. već 1929. M. Chop.

${ }^{52}$ I Musiolova (1846. - 1903.) je knjiga doživjela tri izdanja. Treće je priredio R. Hofmann 1905. godine.

${ }_{53}$ Drugo izdanje Illustrierte Musikgeschichte E. Naumanna (1827. - 1888.) u preradbi E. Schmitza pojavljuje se 1908. da bi do 1934. izašlo 10 izdanja. Godine 1927. manje temeljitu preradbu izvršio je A. Löwen. Usto je knjiga već 1886. prevedena na engleski jezik (F. Praeger) uz dodatna poglavlja o engleskoj glazbi F. A. G. Queseleya, potom na ruski i nizozemski.

${ }^{54}$ Usp. V. NOVAK, 1994, 14. 


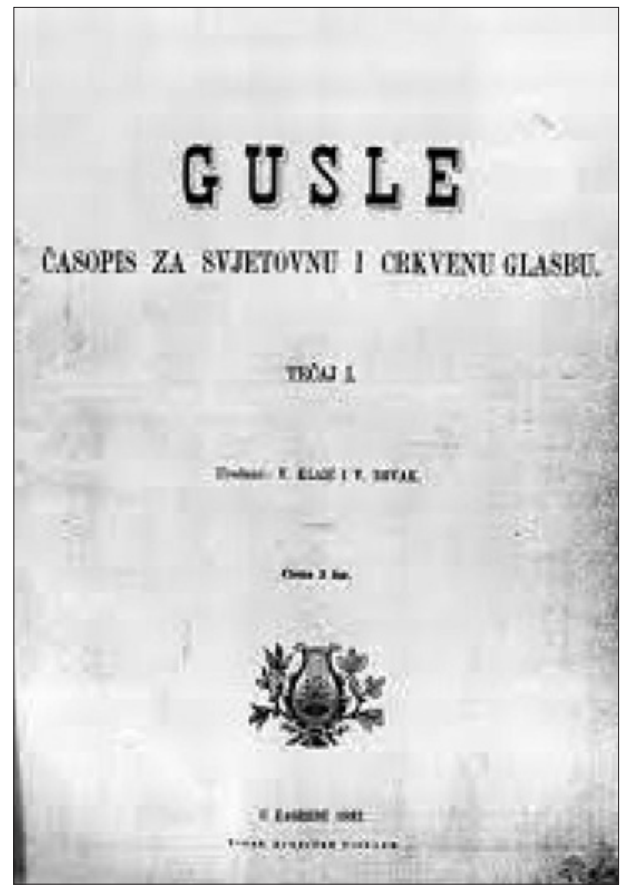

S1. 3. Naslovnica prvoga broja časopisa Gusle. (izvor: http://dnc.nsk.hr/journals/ LibraryTitle.aspx?id=d18cf29b-1b944552-a285-073deace369d) (2019-12-12)
Adlera je riječ o trima velikim stilskim epohama: dobu jednoglasja, dobu višeglasja i razdoblju koje počinje sa 17. stoljećem. $^{55}$ Predstavljajući povijest glazbe kao evolutivan proces, Novak je unutar tih triju velikih razdoblja slijedio, uz manje varijante, standardan raspored građe zastupljen $\mathrm{u}$ onodobnim relevantnim glazbenim povijestima. Usto je inkorporirao i poglavlje o povijesti glazbe južnoslavenskih naroda, poglavito o hrvatskoj, što je bio model koji su i kasnije koristili, doduše ne znajući za Novaka, u svojim općim povijestima glazbe Stjepan Hadrović, Josip Andreis i Nenad Turkalj. ${ }^{56}$ Andreis je u poslijeratnim izdanjima danas već legendarne Povijesti tu koncepciju promijenio. $^{57}$

\section{Neskrivenom simpatizeru} nacionalnih glazbenih pokreta, odnosno stvaranja autonomnih nacionalnih glazbenih kultura

Vjenceslavu Novaku povijest hrvatske glazbe počinje narodnim preporodom, točnije, s prethodnicima mu Ferdom Matakovićem i Grgurom Čevapovićem. Pritom Novak nije bio istraživač već se većinom služio rezultatima Kuhačevih istraživanja, $\mathrm{i}$ to onih objavljenih tiskom, napose njegovim Ilirskim glazbenicima.$^{58}$ Međutim, zanemario je Glasbeno nastojanje Gajevih Ilira iz

${ }^{55}$ Adler je tu podjelu predložio u svom djelu Der Stil in der Musik (1911.), jednom od prvih značajnih muzikoloških radova sistematskog karaktera, koji se bave pitanjem stila u glazbi.

${ }^{56}$ Usp. S. HADROVIĆ, 1911; J. ANDREIS, 1942; N. TURKALJ, 1980.

${ }^{57}$ Usp. J. ANDREIS, 1951. - 1954; Idem, 1962, Idem, 1966; Idem, 1974. - 1977, 1989. Andreisove povijesti glazbe bile su do početka 21. stoljeća najiscrpnije povijesti glazbe u Hrvatskoj te temeljna i nezaobilazna literatura u glazbenim školama i visokim učilištima.

${ }^{58}$ Usp. F. Ks. KUHAČ, 1893. Djelo je objavljeno bez Historijskog uvoda jer ga je Matica hrvatska ocijenila "šovinističkim". Historijski je uvod objavljen tek uz pretisak što ga je priredio Lovro Županović i 1994. objavila Sveučilišna naklada u Zagrebu. 
1885., gdje je Kuhač u uvodnom dijelu naveo "one stare Hrvate [...] koji su do ilirske dobe, nešto uzradili na polju slovjenske glasbe." ${ }^{59} \mathrm{Je}$ li riječ o Novakovu previdu ili svjesnom ispuštanju tih podataka, koje je možda držao nedovoljno provjerenima da bi ušli u udžbenik, teško je sa sigurnošću utvrditi. On je naime Kuhaču javno zamjerio da ne objavljuje sakupljenu građu za povijest južnoslavenskih naroda. ${ }^{60}$ Usto valja imati na umu i njihove turbulentne odnose, što ih je, čini se, inicirala Novakova negativna recenzija Kuhačeve Prve hrvatske upute u glasoviranje. ${ }^{61}$

Kako je već istaknuto, [Povijest glazbe] Vjenceslava Novaka pionirski je rad na području hrvatske glazbene historiografije. Za Novaka je to značilo suočavanje s brojnim problemima: od kriterija izbora odgovarajuće građe do samoga jezika, odnosno terminologije. Kako je ranije navedeno, izbor građe mudro je i uspješno vršio iz tada već standardnih povijesnih priručnika u kojima je bila izložena povijest velikih glazbenih razdoblja, pojedinih skladatelja i skladateljskih poetika, razvoja notnog pisma, glazbenih oblika, teorije, instrumenata, estetskih koncepcija. Te temeljne spoznaje tadašnje glazbene historiografije on je uspješno posredovao jasnim jezikom, premda ponekad uz stanovite terminološke poteškoće, poglavito kad je riječ o hrvatskom glazbenom nazivlju.

\section{Glazbena terminologija}

Napokon, Novak se i sam uključio u rasprave o hrvatskoj glazbenoj terminologiji, što ga je opet dovelo do polemike, ovaj put s Kuhačem. Kuhač je još 1876. godine objavio prijevod Katekizma glazbe Johanna Christiana Lobea (1797. - 1871.), što se drži začetkom procesa standardizacije hrvatske glazbene terminologije, te u pojedinim aspektima traje i danas, ${ }^{62}$ a na koji

${ }^{59}$ F. Ks. KUHAČ, $1885,4$.

${ }^{60}$ Usp. V. NOVAK, 1896, 75.

${ }^{61}$ Usp. L. ŠABAN, 1984, 388-389.

${ }^{62}$ Pitanje standardizacije glazbene terminologije bila je trajna tema hrvatske muzikologije 20 . stoljeća. Tijekom njegova posljednjeg desetljeća glazbena terminologija se intenzivno istraživala u okviru rada na znanstvenom projektu Hrvatska glazbena terminologija Ministarstva znanosti (voditelj je bio Nikša Gligo, a suradnice Sanja Majer-Bobetko i Dubavka Franković). Napokon, Sanja Kiš Žuvela, Tomislava Bošnjak Botica, Ana Ostroški Anić, Nikša Gligo i Krešimir SučevićMeđeral objavili su 2018. u nakladi Odsjeka za muzikologiju Muzičke akademije Sveučilišta u Zagrebu Glazbenički jezični savjetnik, koji je nastao na temelju istraživanja provedenih u okviru projekta Problemi suvremenoga glazbenoga nazivlja u Hrvatskoj (CONMUSTERM) Hrvatske zaklade za znanost (voditelj Nikša Gligo). 
Novak upozorava i u svojoj [Povijesti glazbe]. ${ }^{63}$ Već sljedeće 1877. godine vladinom je odlukom, a nakon povoljne recenzije Franje Markovića, Kuhačeva terminologija predstavljena u Katekizmu glazbe trebala ući u službenu uporabu u svim odjelima škole Narodnoga zemaljskoga glasbenoga zavoda. Do toga očito tada nije došlo jer Novak još 1891. godine piše da se "još do pred godinu dana u našem glazbenom zavodu čula kao od milosti po koja hrvatska riječ i da je $\mathrm{u}$ to razmjerno kratko doba spaljena energijom nove uprave i ta rana, te prestao povod opravdanim tužbama proti prvenstvu nijemštine u srcu Hrvatske." ${ }^{64}$ Rasprave i polemike o glazbenom nazivlju se međutim nastavljaju. Tako je i Kuhačeva rasprava u sarajevskoj Nadi 1896. izravno provocirala Novakov polemički odgovor u Viencu iste godine. ${ }^{65}$

\section{Organologija}

Budući da je kao nastavnik glazbe na Muškoj učiteljskoj školi u Zagrebu predavao i sviranje na orguljama, vjerojatno je potaknut vlastitom praksom posvetio dva članka različitim pitanjima vezanim uz orgulje i svirku na njima. U članku naslovljenom "O čuvanju orgulja"66 Novak upozorava na potrebu stalne brige i održavanja orgulja uz redovite preglede orguljara, a u članku "Nješto o registriranju orgulja"67 progovara o, kako i sam naslov kaže, važnosti registriranja te piše o značajkama osnovnih registara, o mogućim kombinacijama i o uporabi registara, menzuri svirala, visini i boji tona $u$ odnosu na svirale i dr.

\section{Estetika glazbe}

Iz znatnoga dijela Novakovih radova iščitava se i njegovo zanimanje za glazbeno-estetička pitanja, koja stoje kao temeljna potka mnogima od njih. Uostalom, Novak je, koliko je poznato, prvi hrvatski autor koji je pokušao definirati glazbenu estetiku kao dio "obće estetike, t. j. nauke o lijepom. Ona izpituje sućtvo glasbotvorine, razjašnjuje pitanja: Što je glasba? Što joj je sadržina? U kakvom je snošaju s pjesničtvom i s drugim umjetnostima? Itd." 68

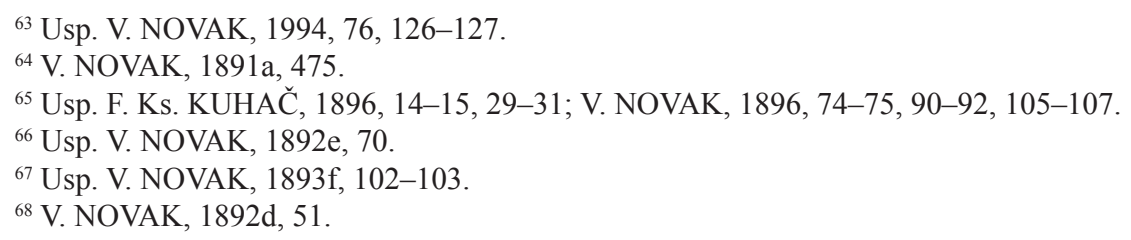


U žarištu Novakova estetičkoga promišljanja stoji središnje pitanje glazbene estetike druge polovice 19. stoljeća: može li glazba izražavati izvanglazbene sadržaje ili ne može, odnosno je li glazba jezik ili nije. Oko tih pitanja vodile su se brojne rasprave te se formirala dva suprotna tabora: 1) formalisti, kojima je čelnik bečki glazbeni kritičar i estetičar glazbe Eduard Hanslick sa svojom glasovitom raspravom O muzički lijepom (Vom MusikalischSchönen) iz 1854. godine, kojoj je u središtu teza da su sadržaj glazbe "forme koje se zvučeći kreću" ("tönend bewegte Formen") i 2) ekspresionisti, koji se vežu uz Liszt-Wagnerovu školu i inzistiraju na romantičkoj težnji k sintezi svih umjetnosti. S tim u vezi onodobna teorija i estetika glazbe razlikovale su apsolutnu glazbu, koja ne izražava ništa osim same sebe, i programnu glazbu, koja ima i izražava izvanglazbeni sadržaj. Takvi glazbeno-estetički stavovi zapravo su u skladu s filozofskim pravcima druge polovice 19. stoljeća: pozitivizmom i romantizmom, gdje se na pozitivizam može gledati kao na svojevrstan romantizam znanosti, koji je filozofiju htio svesti na znanost.

Svoje zanimanje za ove teme Novak je potvrdio i prijevodom vrlo opširne rasprave $O$ programnoj glazbi češkog autora Františeka Picha. To je bio najopsežniji rad s područja glazbene estetike objavljen u 19. stoljeću u Hrvatskoj ${ }^{69} \mathrm{~S}$ druge strane, bio je dobro upoznat i s Hanslickovom tezom o glazbeno lijepom, kojega nekoliko puta i citira, a i sam slijedi, ističući da glazbeno djelo u prvom redu živi od glazbene ljepote, nosioci koje su melodija, harmonija i ritam. O njima opširno raspravlja u člancima objavljenima u časopisu Pobratim,$^{70}$ inzistirajući, opet poput Hanslicka, na autonomnosti glazbe jer "svaka umjetnost ima svoje skroz odjelito područje, koje ima i svoje osobite znakove, nimalo istovjetne sa oznakama područja druge umjetnosti."11

Valja međutim istaknuti da se Novak nije izrijekom opredijelio za antiwagnerijanski tabor, što je razvidno i iz njegova već citiranog rada o Wagneru, već bi se moglo reći da istinu, kako je zaključio Josip Andreis, ${ }^{72}$ traži negdje "po sredini". Umjetnost je za njega idealni medij priopćavanja i način shvaćanja ideje, a uvid u ljepotu ideje pruža ljepota umjetničkog djela. Da u glazbenom djelu treba tražiti glazbenu ljepotu, Novak pokazuje na

${ }^{69}$ Usp. F. PICH, 1893, 10-13, 32-33, 41-44, 50-53, 59-61, 68-70, 77-78, 84-85, 92-94, 100-102. O toj raspravi usp. S. MAJER-BOBETKO, 1979, 41-47.

${ }^{70}$ Usp. V. NOVAK, 1898-1899a, 279-280, 302-303, 327-329; Idem, 1899-1900, 9-11, 35-36+38-39, 86-88; Idem, 1899-1900b, 155-156, 177-179, 207-209, 238-239. O njima usp.: S. MAJER-BOBETKO, 1979, 33-36.

${ }^{71}$ V. NOVAK, 1899-1900b, 155.

72 J. ANDREIS, 1971, 72. 
primjeru Beethovenove Kreutzerove sonate i njezinu značenju u istoimenoj Tolstojevoj noveli. "Beethovenova je sonata", ističe Novak, "umjetnina puna glasbenih ljepota, izvan kojih nije u stvaranju te sonate ništa pomišljao ni Beethoven, niti je itko u pravu tražiti izvan glasbeno lijepoga što drugo u Beethovenovom djelu. $U$ toj je istini sakrivena i uzgojna vrijednost svakog glasbotvora: glasbenik nas uzgaja svojim umotvorima estetski - posredno dakle i etički jerbo nas upoznaje i pruža nam užitak ono, što je lijepo. Svaki je drugi dojam, koji je eto skroz subjektivna, da kažemo, resonanca užitoga glasbotvora, izvan skladateljeve odgovornosti."73 Međutim, u procesu nastajanja i shvaćanja umjetnički lijepoga ključnu ulogu ima "fantazija", ali uz sudjelovanje racionalne komponente. Naime, Novak drži mogućim da, "kad slušamo glazbotvor, u našoj duši odjekuju doista osjećaji što su strujili skladateljevom dušom, dok se u njoj glazbotvor stvarao, ali izim lijepih oblika i tog osjećaja mi ne nalazimo u glazbotvoru ništa - dok nam tajnu ne razgali sam skladatelj kazavši često puta samo sa natpisom, 'šta' imamo slušati u glazbotvoru." 74 A tada, tvrdi Novak, "pomoću fantazije izpunjamo lijepe glazbene oblike s posebnom sadržinom, a estetska vrijednost umjetnine biva po tom dva puta veća" (kurziv S.M.B.), ${ }^{75}$ što je u potpunom proturječju s njegovim uvjerenjem da je jedini relevantan sadržaj glazbenog djela "čista" glazbena ljepota. Stoga bi se moglo zaključiti da njegova estetička misao balansira između romantičkih i pozitivističkih ideja.

\section{Zaključak}

Djelovanje Vjenceslava Novaka kao glazbenoga pisca u najširem smislu nosi u mnogim disciplinama pionirske osobine. Poglavito se to odnosi na činjenicu da je napisao prvu opću povijest glazbe, prve udžbenike harmonije na hrvatskom jeziku, prvi opsežniji članak o Gjuri Eisenhuthu s popisom djela, prvu definiciju estetike i povijesti glazbe, gdje za potonju piše da "izpituje zarodke glasbene umjetnosti kod najstarijih naroda i prati njezin razvitak do danas". ${ }^{76}$ Njegovi članci pripadaju, prema današnjim klasifikacijama, među stručne i pregledne radove te su dragocjeno vrelo istraživanja povijesti hrvatskog glazbenog školstva, kritike, historiografije, estetike, a u manjoj mjeri terminologije i organologije.

\footnotetext{
${ }^{73}$ V. NOVAK, 1892, 10.

${ }^{74} \mathrm{~V}$. NOVAK, 1893b, 4.

${ }^{75}$ Ibid.

${ }^{76}$ V. NOVAK, 1892d, 51.
} 
Napokon, na području glazbene periodike Novak je sudjelovao u dva navrata i kao urednik glazbenih časopisa. Zajedno s Vjekoslavom Klaićem uređivao je časopis Gusle 1892., a sljedeće godine sam se prihvatio uređivanja časopisa Glazba. Nažalost, oba su izlazila samo tijekom jedne godine. Uzrok tome Andreis s pravom vidi u financijskim teškoćama, nedovoljnom broju relevantnih suradnika. Novak nije bio samo urednik već je sam morao pisati i većinu tekstova, u još uvijek premalom korpusu zainteresirane publike. ${ }^{77}$

Uzimajući u obzir svekoliku glazbeno-spisateljsku djelatnost Vjenceslava Novaka može se s punim pravom zaključiti da ona otkriva njegov golem i respektabilan, ali i nedovoljno istican muzikološki potencijal. Ovaj rad nudi spoznaju kako je taj potencijal možda najveći poslije Kuhačeva tijekom Zajčeva i Kuhačeva razdoblja (1870. - 1914.).

\section{Literatura}

\section{Bibliografija radova Vjenceslava Novaka}

\section{a) Kritike i članci (kronologijskim slijedom)}

Pučki učitelj kao učitelj pjevanja i kao orguljaš, Izvještaj Kr. preparandije $i$ vježbaonice u Zagrebu, Zagreb, 1887-88, 3-24; Hrvatski učitelj, 12/15, 12/16, 12/17, 12/18, 12/19, 12/20, Zagreb, 1888, 225-227, 243-245, 259-260, 275-277, 293-294, $310-311,325-326$.

Aphrodita. Opereta u tri čina. Libreto od Nikole Milana, glasba od Ivana pl. Zajca, Narodne novine, 54/4, Zagreb, 1888, s.p.

(Koncert gosp. Aurela Vaisa-Bjelinskoga guslara uz sudjelovanje pijanistice gospodjice Laure Fein.), Narodne novine, 54/4, Zagreb, 1888, s.p.

Gospodinu Nikoli Milanu Simeonoviću, piscu Aphrodite, operete u tri čina, Narodne novine, 54/8, Zagreb, 1888.

(Šaljivi koncert Kola), Narodne novine, 54/34, Zagreb, 1888, s.p.

(Šaljivi koncert Radnič. pjevač. društva Slobode), Narodne novine, 54/36, Zagreb, 1888 , s.p.

Židovka. Velika opera u pet činah od J. Halévy-a, pjevana u Zagrebu, Narodne novine, 54/106, Zagreb, 1888, s.p.

Stabat Mater. Glazbotvor za sola, zborove i orkestar od Antuna Dvořaka, Vienac, 20/14, Zagreb, 1888, 219-223.

${ }^{77}$ Usp. J. ANDREIS, 1971, 76. 
Crtice o razvoju crkvene glasbe, Izvještaj Kralj. učiteljske škole $i$ vježbaonice u Zagrebu, 1888-1889, 3-20; Hrvatski učitelj, 13/17, 13/18, 13/19, Zagreb, 1889, 260-263, 275-278, 290-294.

Nauka glavnih pojmova muzike. (Zašto ne: Glavni pojmovi muzike-ili: Nauka o glavnim pojmovima muzike?) Napisao Dragutin Blažek, Književna smotra, 7/3, Zagreb, 1889, 19-23.

[Opera Hugenoti G. Meyerbeera izvedena je u Zagrebu], Narodne novine, 55/17, Zagreb, 1889 , s.p.

O razvoju crkvene glasbe, Narodne novine, 55/214, Zagreb, 1889, s.p.

(Slovanstvo ve svých zpěvech). Sbornik národnich a znárodnělych pisní vsech slovanskych národu, Narodne novine, 55/296, Zagreb, 1889, Pr.

Neuvelo cvieće. Izabrane popijevke slavnoga hrv. glasbotvorca Vatroslava Lisinskoga. Dvanaest ovećih popijevaka za jedno grlo uz glasovir. Izdanje vlastitom nakladom Fr. Š. Kuhača, Vienac, 2/10, 21/11, Zagreb, 1889, 156-158, 169-171.

Obuka u pjevanju u pučkoj školi, Izvještaj Kr. učiteljske škole i vježbaonice u Zagrebu, 1889-90, 3-14; Hrvatski učitelj, 14/15, 14/16, Zagreb, 1890, 233-236, 248-251.

Pjevački sbor D. Slavjanskoga Agrenjeva, Napredak, 31/9, Zagreb, 1890, 140-141.

Prvi vokalni koncert u narodnom zem. glazb. zavodu, Vienac, 22/23, Zagreb, 1890, 366367.

Popijevke u I. vokalnom koncertu narod. zem. glazb. zavoda, Vienac, 22/25, 22/26, Zagreb, 1890, 394-395, 409-410.

Dvořakov Hymnus domovini izvođen u koncertu Narod. zem. glazb. zavoda, Vienac, 22/48, 22/49, Zagreb, 1890, 770-772, 786-787.

Čemu se uči teorija glasbe? Izvješće Narodnog zemaljskog glasbenog zavoda, Zagreb, 1891, 3-7; Gusle, 1/6, 1/7, Zagreb, 1892, 47, 50-51.

Mozartov Requiem, Narodne novine, 57/91, Zagreb, 1891, s.p.

Pripomenak, Starohrvatske crkvene popievke, Knjižara Dioničke tiskare, Zagreb, 1891, $3-5$.

Prvi komorni koncerat u Nar. zemaljskom glazbenom zavodu. (Nekoliko riečih u napried), Narodne novine, 57/283, Zagreb, 1891, s.p.

Stvaranje svijeta. Oratorij Josipa Hajdna, Vienac, 23/10, Zagreb, 1891, 154-156.

Preustrojstvo Nar. zem. glazbenog zavoda u Zagrebu, Vienac, 23/30, Zagreb, 1891, 475478.

Glasba i uzgoj, Gusle, 1/1, 1/2, 1/3, Zagreb, 1892, 2-3, 9-11, 17-18.

O pjevanju u pučkoj školi obzirom na dječje zdravlje, Gusle, 1/1, Zagreb, 1892, 4-5.

O mutaciji grla, Gusle, 1/5, Zagreb, 1892, 33-35.

Moraju li sva djeca pjevati u pučkoj školi?, Gusle, 1/5, Zagreb, 1892, 36-37.

O čuvanju orgulja, Gusle, 1/9, Zagreb, 1892, 70.

Historički razvitak obuke u pjevanju, Pjevačka obuka u pučkoj školi, Knjižara dioničke tiskare (knjižara Jugoslavenske akademije), Zagreb, 1892, 44-58. 
Ivan pl. Zajc, Glazba, 1/1, Zagreb, 1893, 1-3. Atribucija: Sanja Majer-Bobetko prema usporedbi s člankom Ivan pl. Zajc, Pobratim,10/2, 10/5, Zagreb, 1899-1900, 31, 104-105.

Oblik i sadržina u glazbotvorinama, Glazba, 1/1, Zagreb, 1893, 3-4.

Prije ljestvice - pa onda intervale, Glazba, 1/2, Zagreb, 1893, 13-14.

Falstaff, Glazba, 1/3, Zagreb, 1893, 24-25.

Gjuro Eisenhut, Glazba, 1/7, Zagreb, 1893, 57-59.

Kako započeti glazbenu obuku?, Glazba, 1/8, Zagreb, 1893, 66-68.

[K. A. Hermann: Völkerlieder für voerstimmige Männerchöre], Glazba, 1/11, Zagreb, 1893, 11, 91-92.

Nješto o registriranju orgulja, Glazba, 1/12, Zagreb, 1893, 102-103.

Prilog k hrvatskom glasbenom nazivlju, Vienac, 28/5, 28/6, 28/7, Zagreb, 1896, 74-75, 90-92, 105-107.

Nova zbirka popievaka, Prosvjeta, 6/20, Zagreb, 1898, 644-645.

Ambroise Thomas, Pobratim, 9/5, Zagreb, 1898-99, 99+108-110.

Glazbeni ritam, Pobratim, 10/12, 19/13, 19/14, Zagreb, 1898-1899a, 279-280, 302-303, 327-329.

O melodiji, Pobratim,10/1, 19/2, 10/4, Zagreb, 1899-1900, 9-11, 35-36+38-39, 86-88.

Ivan pl. Zajc, Pobratim,10/2, 10/5, Zagreb, 1899-1900,31, 104-105.

O glazbenoj harmoniji, Pobratim,10/7, 10/8, 19/9, 10/10, Zagreb, 1899-1900b, 155-156, 177-179, 207-209, 238-239.

Richard Wagner, Pobratim, 10/18, 10/19, Zagreb, 1899-1900, 437-439, 459-462.

Počeci višeglasja do Palestrine, Kršćanska škola, 4/3, 4/4, Zagreb, 1900, 42-45, 62-67.

Glasovni ustroji, Pedagogijska enciklopedija, ur. Stjepan Basariček et al., Hrvatski pedagoško-književni zbor, Zagreb, 1900, knj. I, sv. 6, 372-378.

O nuždi reforme pjevačke obuke u našim srednjim školama, Nastavni vjesnik, 9, Zagreb, 1901, 310-320.

Glazbena obuka, Pedagogijska enciklopedija, ur. Stjepan Basariček et al., Hrvatski pedagoško-književni zbor, Zagreb, 1901, knj. I, sv. 7, 386-392.

Glazbene škole, Pedagogijska enciklopedija, ur. Stjepan Basariček et al., Hrvatski pedagoško-književni zbor, Zagreb, 1901, knj. I, sv. 7, 392-393.

O zbornoj skladbi Dragutina Kukle na riječi Marka Marulića, Vienac, 33/42, Zagreb, $1901,856$.

Naša crkvena glazba. Tri mise sa starohrvatskim riječima za muški zbor od K. Kukle, Vienac, 35/6, 35/8, Zagreb, 1903, 196-197, 261-263.

Koral, Pedagogijska enciklopedija, ur. Stjepan Basariček et al., Hrvatski pedagoškoknjiževni zbor, Zagreb, 1906, knj. I, sv. 11, 643-645.

\section{b) Monografska izdanja (kronologijskim slijedom)}

Priprava k nauci o glazbenoj harmoniji, Zagreb, 1889.

Nauka o glasbenoj harmoniji, Kralj. hrv.-slav.-dalm. zemaljska vlada, Zagreb, 1890. 
Nauka o glazbenoj harmoniji, Kralj. hrv.-slav.-dalm. zemaljska vlada, Zagreb, ${ }^{2} 1898$.

Uspomena na vokalne koncerte priredjene dne 30. svibnja i 2. lipnja 1890 u Narodnom zem. glasbenom zavodu, Zagreb, 1890.

Starohrvatske crkvene popievke, Knjižara Dioničke tiskare, Zagreb, 1891.

Pjevačka obuka u pučkoj školi, Knjižara dioničke tiskare (knjižara Jugoslavenske akademije), Zagreb, 1892.

Uputa u orguljanje, Lav Hartman, Zagreb, 1893.

c) Rukopis

[Povijest glazbe], cca 1890-1900, Knjižnica Muzičke akademije Sveučilišta u Zagrebu, str. 237, nepotpuno. Kritičko izdanje priredila Sanja Majer-Bobetko (Croatica, 25/40-41, 1994, 1-200).

\section{d) Prijevod}

František PICH, Prvi pojavi programne glazbe do Beethovena, Glazba, 1/2, 1893, 1013; O programnoj glazbi, 1/4, 1/5, 1/6, 1/7, 1/8, 1/9, 1/10, 1/11, 1/12, Zagreb, $1893,32-33,41-44,50-53,59-61,68-70,77-78,84-85,92-94,100-102$.

\section{Knjige i članci korišteni u radu}

Josip ANDREIS, Povijest glazbe, Matica hrvatska, Zagreb, 1942.

Josip ANDREIS, Historija muzike (3 sv.), Školska knjiga, Zagreb,1951-1954.

Josip ANDREIS, Historija muzike (2 sv.), Školska knjiga, Zagreb, 1966.

Josip ANDREIS, Prvi muzički časopisi u Hrvatskoj, Arti musices, 2, Zagreb, 1971, 5380.

Josip ANDREIS, Povijest glazbe (4 sv.), Liber - Mladost, Zagreb, 1974-1977. (pretisak Sveučilišna naklada Liber, Zagreb 1989).

Josip ANDREIS- Dragotin CVETKO- Stana ĐURIĆ-KLAJN, Historijski razvoj muzičke kulture u Jugoslaviji, Školska knjiga, Zagreb, 1962.

Gorana DOLINER, Novak o povijesti crkvene glazbe, u: Sanja MAJER-BOBETKO Zdravko BLAŽEKOVIĆ - Gorana DOLINER, Hrvatska glazbena historiografija u 19. stoljeću, Hrvatsko muzikološko društvo, Zagreb, 2009, 115-118.

Dubravka FRANKOVIĆ, Još o povijesti "Povijesti glazbe" Vjenceslava Novaka, Kolo, 12/1, Zagreb, 2002, 19-34.

Antun GOGLIA, Gjuro Eisenhuth, Sv. Cecilija, 20/2, Zagreb, 1926, 37-48. (objavljeno i kao separat, Zagreb, 1926.)

Stjepan HADROVIĆ, Kratka povjest glazbe, Vlastita naklada, Zagreb, 1911.

Vjekoslav KLAIĆ, Rikard Wagner, Vienac, 15/8, Zagreb, 1883, 133-134.

Koraljka KOS, Vatroslav Lisinski: Teorija sloga tonske umjetnosti, Zvuk, 96-97, Sarajevo, 1969, 279-286. 
Franjo Ks. KUHAČ, Glasbeno nastojanje Gajevih Ilira, Povjesna crtica, Mučnjak i Senftleben, Zagreb, 1885.

Franjo Ks. KUHAČ, Ilirski glazbenici: Prilozi za poviest hrvatskoga preporoda, Matica hrvatska, Zagreb 1893.

Franjo Ks. KUHAČ, Hrvatsko glazbeno nazivlje, Nada, 2/1, 2/2, Sarajevo, 1896, 14-15, 29-31.

Franjo Ks. KUHAČ, Rikard Wagner i glazbeni mu smjer, Prosvjeta, 5/3, 5/4, Zagreb, 1897, 91-94, 107-111.

Zofia LISSA, O povijesnoj promjenljivosti glazbenog primalaštva, Estetika glazbe / ogledi/, prev. Stanislav Tuksar, Naprijed, Zagreb, 1977, 71-86.

Mijo MAJER, (Crtice o razvoju crkvene glasbe.). Razpravio Vjenceslav Novak, Narodne novine, 55/207, Zagreb, 1889, 207.

Sanja MAJER-BOBETKO, Estetika glazbe u Hrvatskoj u 19. stoljeću, JAZU, Zagreb, 1979, 17-29.

Sanja MAJER-BOBETKO, Glazbeno-estetska problematika u napisima Franje Kuhača, Zbornik radova sa znanstvenog skupa održanog u povodu 150. obljetnice rođenja Franje Ksavera Kuhača (1834-1911), ur. Jerko Bezić, JAZU, Zagreb, 1984, 441459.

Vjenceslav NOVAK, Pučki učitelj kao učitelj pjevanja i kao orguljaš, Izvještaj Kr. preparandije $i$ vježbaonice u Zagrebu, Zagreb, 1887-88, 3-24.

Vjenceslav NOVAK, Pučki učitelj kao učitelj pjevanja i kao orguljaš, Hrvatski učitelj, 12/15, 16, 17, 18, 19, 20, 21, Zagreb, 1888, 225-227, 243-245, 259-260, 275277, 293-294, 310-311, 325-326.

Vjenceslav NOVAK, Aphrodita. Opereta u tri čina. Libreto od Nikole Milana, glasba od Ivana pl. Zajca, Narodne novine, 54/4, Zagreb, 1888a.

Vjenceslav NOVAK, Crtice o razvoju crkvene glasbe, Izvještaj Kralj. učiteljske škole $i$ vježbaonice u Zagrebu, Zagreb, 1888-1889, 3-20.

Vjenceslav NOVAK, Crtice o razvoju crkvene glasbe, Hrvatski učitelj, 13/17, 13/18, 13/19, Zagreb, 1889a, 260-263, 275-278, 290-294.

Vjenceslav NOVAK, Priprava k nauci o glazbenoj harmoniji, Zagreb, 1889.

Vjenceslav NOVAK, Nauka glavnih pojmova muzike. (Zašto ne: Glavni pojmovi muzike -ili: Nauka o glavnim pojmovima muzike?) Napisao Dragutin Blažek, Književna smotra, Zagreb, 7/3, 1889b, 19-23.

Vjenceslav NOVAK, (Slovanstvo ve svých zpěvech). Sbornik národnich a znárodnělych pisní vsech slovanskych národu, Narodne novine, 55/296, Zagreb, 1889b, Pr.

Vjenceslav NOVAK, O razvoju crkvene glasbe, Narodne novine, 55/214, Zagreb, 1889c.

Vjenceslav NOVAK, Neuvelo cvieće. Izabrane popijevke slavnoga hrv. glasbotvorca Vatroslava Lisinskoga. Dvanaest ovećih popijevaka za jedno grlo uz glasovir. Izdanje vlastitom nakladom Fr. Š. Kuhača, Vienac, 21/10, 11, Zagreb, 1889d, 156-158, 169-171. 
Vjenceslav NOVAK, Obuka u pjevanju u pučkoj školi, Izvještaj Kr. učiteljske škole $i$ vježbaonice u Zagrebu, Zagreb, 1889-90, 3-14.

Vjenceslav NOVAK, Obuka u pjevanju u pučkoj školi, Hrvatski učitelj, 14/15, 14/16, Zagreb, 1890a, 233-236, 248-251.

Vjenceslav NOVAK, Nauka o glasbenoj harmoniji, Kralj. hrv.-slav.-dalm. zemaljska vlada, Zagreb, 1890.

Vjenceslav NOVAK, Čemu se uči teorija glasbe? Izvješće Narodnog zemaljskog glasbenog zavoda Zagreb, Zagreb, 1891, 3-7.

Vjenceslav NOVAK, Preustrojstvo nar. zem. glazbenog zavoda u Zagrebu, Vienac, 23/30, Zagreb, 1891a, 475-478.

Vjenceslav NOVAK, Glasba i uzgoj, Gusle, 1/1, 1/2, 1/3, Zagreb, 1892, 2-3, 9-11, 1718.

Vjenceslav NOVAK, O pjevanju u pučkoj školi obzirom na dječje zdravlje, Gusle, 1/1, Zagreb, 1892a, 4-5.

Vjenceslav NOVAK, O mutaciji grla, Gusle, 1/5, Zagreb, 1892b, 33-35.

Vjenceslav NOVAK, Moraju li sva djeca pjevati u pučkoj školi?, Gusle, 1/5, Zagreb, 1892c, 36-37.

Vjenceslav NOVAK, Čemu se uči teorija glasbe? Gusle, 1/6, 1/7, Zagreb, 1892d, 47, $50-51$.

Vjenceslav NOVAK, O čuvanju orgulja, Gusle, 1/9, Zagreb, 1892e, 70.

Vjenceslav NOVAK, Historički razvitak obuke u pjevanju, Pjevačka obuka u pučkoj školi, Knjižara dioničke tiskare (knjižara Jugoslavenske akademije), Zagreb, 1892f, 44-58.

Vjenceslav NOVAK, Uputa u orguljanje, Lav Hartman, Zagreb, 1893.

Vjenceslav NOVAK, Ivan pl. Zajc, Glazba, 1/1, Zagreb, 1893a, 1-3.

Vjenceslav NOVAK, Oblik i sadržina u glazbotvorinama, Glazba, 1/1, Zagreb, 1893b, 3-4.

Vjenceslav NOVAK, Prije ljestvice-pa onda intervale, Glazba, 1/2, Zagreb, 1893c, 1314.

Vjenceslav NOVAK, Gjuro Eisenhut, Glazba, 1/7, Zagreb, 1893d, 57-59.

Vjenceslav NOVAK, [K. A. Hermann: Völkerlieder für voerstimmige Männerchöre], Glazba, 1/11, Zagreb, 1893e, 91-92.

Vjenceslav NOVAK, Nješto o registriranju orgulja, Glazba, 1/12, Zagreb, 1893f, 102103.

Vjenceslav NOVAK, Glazbene škole, Pedagogijska enciklopedija, ur. Stjepan Basariček et al., Hrvatski pedagoško-književni zbor, Zagreb, 1895-1906, sv. I, 392-393.

Vjenceslav NOVAK, Prilog k hrvatskom glazbenom nazivlju, Vienac, 28/5, 28/6, 28/7, Zagreb, 1896, 74-75, 90-92, 105-107.

Vjenceslav NOVAK, Nauka o glazbenoj harmoniji, Kralj. hrv.-slav.-dalm. zemaljska vlada, drugo izdanje, Zagreb, 1898. 
Vjenceslav NOVAK, Nova zbirka popievaka, Prosvjeta, 6/20, Zagreb, 1898a, 20, 644645.

Vjenceslav NOVAK, Ambroise Thomas, Pobratim, 9/5, Zagreb, 1898-99, 99+108-110.

Vjenceslav NOVAK, Glazbeni ritam, Pobratim, 10/12, 10/13, 10/14, Zagreb, 18981899a, 279-280, 302-303, 327-329.

Vjenceslav NOVAK, O melodiji, Pobratim, 10/1, 10/2, 10/4, Zagreb, 1899-1900, 9-11, 35-36+38-39, 86-88.

Vjenceslav NOVAK, Ivan pl. Zajc, Pobratim,10/2, 10/5, Zagreb, 1899-1900a, 31, 104105.

Vjenceslav NOVAK, O glazbenoj harmoniji, Pobratim,10/7, 10/8, 10/9, 10/10, Zagreb, 1899-1900b, 155-156, 177-179, 207-209, 238-239.

Vjenceslav NOVAK,Richard Wagner, Pobratim, 10/18,10/19, Zagreb, 1899-1900c, 437-439, 459-462.

Vjenceslav NOVAK, Počeci višeglasja do Palestrine, Kršćanska škola, 4/3, 4/4, Zagreb, 1900, 42-45, 62-67.

Vjenceslav NOVAK, Glasovni ustroji, Pedagogijska enciklopedija, ur. Stjepan Basariček et al., Hrvatski pedagoško-književni zbor, Zagreb, 1900a, knj. I, sv. 6, 372-378.

Vjenceslav NOVAK, O nuždi reforme pjevačke obuke u našim srednjim školama, Nastavni vjesnik, 9, Zagreb, 1901, 310-320.

Vjenceslav NOVAK, Glazbena obuka, Pedagogijska enciklopedija, ur. Stjepan Basariček et al., Hrvatski pedagoško-književni zbor, Zagreb, 1901a, knj. I, sv. 7, 386-392.

Vjenceslav NOVAK, O zbornoj skladbi Dragutina Kukle na riječi Marka Marulića, Vienac, 33/42, Zagreb, 1901b, 856. Skladba je objavljena na str. 848-849.

Vjenceslav NOVAK, Naša crkvena glazba. Tri mise sa starohrvatskim riječima za muški zbor od K. Kukle, Vienac, 35/6, 35/8, Zagreb, 1903, 196-197, 261-263.

Vjenceslav NOVAK, [Povijest glazbe], priredila Sanja Majer-Bobetko, Croatica, 25/4041, Zagreb, 1994, 1-200.

František PICH, Prvi pojavi programne glazbe do Beethovena, Glazba, 1/2, 1893, Zagreb, 10-13; O programnoj glazbi, 1/4, 1/5, 1/6, 1/7, 1/8, 1/9, 1/10, 1/11, 1/12, 1893, Zagreb, 32-3, 41-44, 50-5, 59-61, 68-7, 77-7, 84-85, 92-94, 100-102.

Nikola Milan SIMEONOVIĆ, Nekoj gospodi kritičarom!, Narodne novine, 54/6, Zagreb, 1888, 6 .

Ladislav ŠABAN, 150 godina Hrvatskog glazbenog zavoda, HGZ, Zagreb, 1982.

Ladislav ŠABAN, Didaktički radovi Franje Ksavera Kuhača, u: Jerko Bezić (ur.),Zbornik radova sa znanstvenog skupa održanog u povodu 150. obljetnice rođenja Franje Ksavera Kuhača (1834-1911), JAZU, Zagreb 1984, 387-403.

Nediljka s. Mirja TABAK, Doprinos Vjenceslava Novaka Hrvatskoj crkvenoj glazbi, Hrvatska obzorja, 9/2, Split, 2001, 407-426.

Nenad TURKALJ, Historija muzike, Naprijed, Zagreb, 1980. 


\section{VJENCESLAV NOVAK - THE MUSICAL WRITER}

\section{Summary}

Vjenceslav Novak $(1859-1905)$ is generally known to the Croatian cultural public as a writer. It is less well-known that he was one of the few Croatian musicians with an excellent formal higher education in music. In 1886 he acquired the title of organist at the Prague Conservatory, and in 1887 he was a teacher of singing and music theory. Therefore, he was able to provide for himself and his family as a professor of various musical subjects in the Male Teacher-Training School and the school of the Croatian Music Institute in Zagreb. Along with this, from 1888 he published numerous articles in periodicals and monographs for 15 years. These works reveal the wide range of Novak's professional interests: from musical criticism via theory, pedagogy, methodology, organology and the aesthetics of music, to musical historiography, which, along with the founder of Croatian musicology in general, Franjo Ksaver Kuhač (1834-1911), makes him a leading writer of music from the turn of the $19^{\text {th }}$ into the $20^{\text {th }}$ century.

His first works belong to the field of musical pedagogy and music criticism. He was the author of the first textbooks about the harmony in the Croatian language (1889, 1890 and 1898), Upute $u$ orguljanje (How to play the organ) (1893), intended for teaching organ playing and numerous other works, in which he talks about various themes, from the most general views of music schooling and questions in relation to music and education, where he also touches upon the musical-social problematics of the unsatisfactory social position of music and musicians, to training in singing, which includes the problem of children's health, voice-breaking, music theory and methodology. Novak's small number of musical reviews mainly reveal a critic who strives and often manages to explain his views in a reasoned and expert way.

From 1889 Novak directed his attention to music historiography. The central place in this work belongs to his musical-literary opus of the first Croatian music-historiographical synthesis, the monograph [Povijest glazbe / History of Music], in which, in addition to the general history of music, he presents the history of the music of the South Slavic peoples, mainly Croatian history.However, it remained in a manuscript form right up until 1994. The writing of such a history for Croats meant that Novak faced numerous problems; from the criteria of the choice of appropriate material to the language itself, in other words, the terminology.He wisely and successfully made the choice of material from the then already standard historical manuals, and he successfully conveyed the basic knowledge of the then music historiography in a clear language, although sometimes with certain terminological difficulties, particularly when it came to Croatian musical terminology. Therefore, it is no surprise that he himself became involved in discussions about Croatian musical terminology, which led him into a dispute with Kuhač. Furthermore, since he also taught organ playing as a music teacher, he was probably encouraged by his own practice to dedicate two articles to the various issues related to the organ and the playing of it. Finally, from a considerable part of Novak's works his interest in musical-aesthetic issues, which stand as a fundamental thread for many of them, can also be read.Novak's aesthetic thought balances between romantic ideas that were promoted by the expressionists, insisting on the pursuit of the synthesis of all arts (the Liszt-Wagner school) and positivist ideas, advocated by the formalists, who hold "pure" musical beauty the only relevant content of a musical work (Eduard Hanslick).

The work of Vjenceslav Novak as a music writer in the broadest sense bears pioneering characteristics in many disciplines. Finally, in the field of music periodicals, Novak also participated as the editor of music magazines on two occasions. Together with Vjekoslav 
Klaić, he edited Gusle (1892), and then Glazba himself (1893). Taking into account the overall musical-writing activity of Vjenceslav Novak, it can be rightly concluded that it reveals his large and respectable, as well as insufficiently emphasised musicological potential.

Keywords: Vjenceslav Novak, music writer, music critic, music pedagogy, music historiography, history of Croatian music 